\title{
STUDENTS' DIFFICULTIES IN WRITING NARRATIVE TEXT
}

\author{
${ }^{1}$ Manisha Koilara, ${ }^{2}$ Four Satria Tambunan, ${ }^{3}$ Diana Romaito Hutabarat, \\ ${ }^{4}$ Sri Ninta Tarigan \\ Prima Indonesia Univesity \\ E-mail: ${ }^{1}$ manishakoilara1996@gmail.com, ${ }^{2}$ fourtambunan27@ gmail.com, \\ 33ianahutabarat123@gmail.com, ${ }^{4}$ srinintatarigan@ unprimdn.ac.id
}

\begin{abstract}
This research aims to describe students' difficulties in writing narrative texts, the students' more dominant problems and to know English teacher action to solve the problem. The researchers used qualitative research and a descriptive case study. This study tries to observe students' mistakes in writing narrative texts. The data collected based on the students' answer sheet. The categories made based on the students' answer sheets in writing Narrative texts. The things that recorded by the researchers for giving scores are the four generic structures: Orientation, Complication, Resolution, and Re-Orientation/Coda. And the researchers found that the students still had difficulties in writing narrative texts with the generic structures. Based on the findings, from 26 students only 3 students can distinguish between parts of generic structures and the rest must practice at home and ask the teacher to make improvements.
\end{abstract}

Keywords: Students' difficulties, Writing, Narrative text

\begin{abstract}
Abstrak
Penelitian ini bertujuan untuk menggambarkan kesulitan siswa dalam menulis teks naratif, masalah yang lebih dominan siswa dan untuk mengetahui tindakan guru bahasa Inggris untuk menyelesaikan masalah. Para peneliti menggunakan penelitian kualitatif dan studi kasus deskriptif. Penelitian ini mencoba mengamati kesalahan siswa dalam menulis teks naratif. Data dikumpulkan oleh berdasarkan pada lembar jawaban siswa. Kategori dibuat berdasarkan lembar jawaban siswa dalam menulis teks Naratif. Hal-hal yang dicatat oleh para peneliti untuk memberikan skor adalah empat struktur generik: Orientasi, Komplikasi, Resolusi, dan Re-Orientasi / Coda. Dan para peneliti menemukan bahwa para siswa masih mengalami kesulitan dalam menulis teks naratif dengan struktur generik. Berdasarkan temuan, dari 26 siswa hanya 3 siswa yang dapat membedakan antara bagian struktur generik dan sisanya harus berlatih di rumah dan meminta guru untuk melakukan perbaikan.
\end{abstract}

Kata kunci: Kesulitan siswa, Menulis, Teks naratif 


\section{INTRODUCTION}

English is one of the languages that is known as an International Language. In education, English is a foreign language and it is an obligatory subject that learned in school. English has been taught to the students in all grades in school. Since English has been a foreign language in Indonesia, many achievements needed in teaching and learning in school. Learning English is a complex process that included components such as Grammar and Vocabulary. English as subject material in school has four basic language skills, they are reading, writing, speaking, listening.

Writing is one skill of language that should be mastered by people in the world. Writing is the act of communication by using paper. The purpose is to express ideas, taught and feels. Students can illustrate their impulsion by writing. One of the genres in writing is Academic writing which is used in school or college. There are four types of writing:

1. Expository - Writing in which author wants to inform or explain something to the reader.
2. Persuasive - Writing in which the author states an opinion and attempts to influence the reader.

3. Narrative - Writing in which the author tells a story.

4. Descriptive - A type of expository writing which is the author try to describe something.

According to King (2004), Writing skills is a comprehensive writing program for beginning, struggling, at-risk, or reluctant writers. For these writers, this structured program provides an essential foundation in thinking and writing skills. For proficient and advanced writers, it offers strategies, techniques, and opportunities to apply them. Writing Skills provides special instruction in spelling, handwriting, and keyboarding, and addresses important skills that many writing curricula take for granted.

According to Oshima and Hogue (2007), Academic writing is the kind of writing used in high school and college classes. Academic writing is different from free essay writing, which is the type of writing when you want to write a story. 
Academic writing is also different from personal writing, which is the type of writing used to write personal messages to friends and family. The steps of writing Academic Writing can be described as follows. The first step taken before writing Academic Writing is called pre-writing. Pre-writing is a series of processes to gather and get ideas on an article. In this step, the main goal is to choose a topic and gather ideas to explain the topic. Some of the methods below can be used to get ideas, are as follows:

\section{a. Listing}

The first of pre-writing technique is listing process in which you write the topic at the top of a piece of paper and then quickly make a list of words or phrases that come into your mind.

\section{b. Organizing}

The second pre-writing technique is the organizing process in which you organize ideas into a simple outline. After the first sentence, you can list the two main ideas and any other information to give a piece of complete information.

\section{c. Writing}

The third of the pre-writing technique is writing a rough draft, using your outline as a guide. Write your rough draft as quickly as you can without stopping to think about grammar, spelling, and punctuation. Just get your ideas into your paper.

\section{d. Polishing (Revising and Editing)}

Fourth, the pre-writing method is polishing (revising and editing). In this step, the author tries to give the finishing touches by polishing the writing that has been made. This step is also called revising and editing. Polishing will be far more successful if the writer takes these two steps. First, it directly refers to the main issues of content and organization (revised). Then work on smaller grammar, punctuation and mechanics problems (editing).

The narrative is the type of writing texts that happened in the past to entertain people.. Narrative texts are also one kind of reading texts taught to Senior High School students. Types of Narrative texts: Folklores, fairy stories, fables, myths and horror stories. They are the generic structures of narrative texts: 


\section{a. Orientation}

Orientation is the beginning of writing that must be issued. This orientation is often referred to as "introduction".

\section{b. Complication}

Complications are conditions where a problem arises slowly and then peaks (climax) in an event.

\section{c. Resolution}

Resolution is the final condition or event in which the problems that occur in the "complications" section subside and be resolved. The end of this problem will generally end happily or sadly.

\section{d. Reorientation/Coda}

In this section, the entire set of events that occurred has been fully intertwined and related to each other from beginning to end so that observers can take moral lessons and new insights from a series of stories that occur.

According to Smalley and Ruelten (1986), there are principally two types of writing that require chronological development: narration and process description. Although the narration usually refers to telling of a story, the term is used here to describe the relating of an experience. The experience may originate from an event in the past (past narratives) or perhaps certain experiences that occurred in the past (usually people do) or may occur now (present narratives). In narrative texts, the topic should be chronological development, and the sentences are arranged in chronological order. It is important in writing narrative texts to show the reader the time relationship between sentences and ideas; clarifying the time relationship helps to achieve coherence. Example of time sequences in narrative texts: first, next, second, then, last, finally.

Based on the researchers' experience when doing teaching practice at school. The researchers found many difficulties that students faced in writing narrative texts. This is the reason why the researchers want to conduct this study.

To support this research, researchers used several references from previous studies that have been carried out and can then be used as references in this study. The first is, Aryanty (2017). This study aims to examine the percentage of errors 
made by students in using English grammar, especially grammar in the past tense. At the same time, the purpose of this study was to determine the students' ability to write narrative texts in grade $8, \mathrm{SMP}$ Negeri 7 Tanjung Pinang in the 20162017 school year. This is based on the problems faced by students in writing narrative texts. The problem they face is the lack of students' ability to use past tense grammar in English when writing the narrative texts. The sample of this study was from class VIII 9 with a total of 42 students. The method used by the researcher was cluster sampling. The method used to collect data in this study is a written test. Data were analyzed using the average formula and the percentage manual formula. The results of this study are (1) the percentage of students' mistakes in using past grammar is very high when compared to, (2) the ability of students to write narrative texts in eighth grade at SMP Negeri 7 Tanjungpinang is good.

Second, Herlinawati (2011). This study aims the most common difficulties made by $3^{\text {rd }}$-grade students in making simple past tenses and divides into two parts: regular and irregular verbs. The findings from this study reveal that most students make common mistakes in random form, the rest make mistakes in normal form. In this study, the researchers used descriptive analysis in qualitative methods. The results of the research carried out are (1) the researcher explains again the random shapes made by the students during the research to ensure students make mistakes (2) Teachers are expected to be more creative in teaching writing, thus making them interesting to learn more, and (3) Teachers should motivate their students to help develop their minds so that students feel more motivated to do more.

Third, Nuhzatun (2016). This study together aims to determine the percentage level of problems faced by second-grade students of SMKN 1 Praya Tengah in writing narrative texts. This study was designed as a qualitative study that completed a descriptive case study and focused on the analysis of errors made by students. The subjects in this study were second-grade students of Praya 
1 Middle School for the 2015/2016 Academic Year consisting of 460 students. Twenty students came from class XI Accounting 1 which later the data collected would be used as a sample. The form of the test is, written and interviewed. The data from the writing test is the main research data that will be used as research material in the process of data analysis and, the data from the interview are secondary data which will then be used as a reference for researchers to obtain a high level of data accuracy. The data collected is then analyzed through the stages that were previously planned in the Implementation Method such as identification, description, and explanation. After the researcher is ready to analyze the data, the results of the study are displayed to reveal the main problems faced by secondgrade students of SMKN 1 Praya Tengah in writing narrative texts is the use of sentence structure (tense) and vocabulary/diction (articles, prepositions, and pronouns). Also, the level of difficulty in determining ideas, difficulty in choosing the right vocabulary, and difficulty in translating writing from Indonesian into English is another problem for students who are considered quite difficult to solve in writing narrative texts.

Fourth, from Diniya (2013). The research conducted aims to investigate what are the abilities and difficulties of students in writing narrative texts as "natural" text genres. This study also focused on the disclosure of the types of processes and conditions that students use in their narrative texts viewed from the transitivity system. This research was conducted at one of the state high schools in Purwakarta. This research design is a case study research design. The research data are thirtyfive student works categorized into three different achievement levels, namely low, medium and high achievers. The findings of this study indicate that the common mistakes students make in their writing are errors of verb patterns, sentence sprawl, and punctuation.

Based on the explanation above, the researchers conclude the research title as "Students' 
Difficulties in Writing Narrative Texts".

Based on the background above, the writers formulated the problem of the study:

1. What difficulties are faced by students in writing narrative texts?

2. What difficulties are more dominant faced by students in writing narrative texts?

3. How do English Teachers solve the students' difficulties in writing narrative texts?

Based on the problem of the study above, the writers formulated the objectives of the study:

1. To find out the students' difficulties in writing narrative texts.

2. To find out the students' more dominant difficulties in writing narrative texts.

3. To know the English Teachers' actions to solve the students' difficulties in writing narrative texts.

\section{METHOD}

These parts explain the purpose of research, place and time of research, research design, the instrument of research, the technique of data analysis, object of research and the procedure in collecting data.

The purpose of this research is to know the problems that students faced in writing narrative texts. Furthermore, this research was conducted in SMA Pangeran Antasari Medan at Jalan Veteran No.1060/19 Helvetia, Kecamatan Labuhan Deli, Kabupaten Deli Serdang. And this research will be conducted from July until September. Then this research is designed to be Qualitative Research which will be accomplished by using a descriptive case study and use the error analysis procedure itself. This study tries to observe the mistakes made by students in writing a narrative text when they want to write narrative texts. The researchers find difficulties and make improvements.

Moreover, the instrument is used to collect data. In this research, the researcher will use direct observation. The researcher will observe the learning process in the 
classroom and find the difficulties faced by students in writing narrative texts.

Additionally, the objects of this study were the students of SMA Pangeran Antasari Medan. The procedure in collecting data, the researcher will adjust this following procedure:

1. The researchers come into the class,

2. The researchers give a text to the students,

3. The researchers ask the students to write the narrative texts on a piece of paper and the topic has been given by the researchers,

4. The researchers give the students time to write the narrative texts,

5. The researchers collect the students' assignment,

6. The researchers find and know the students' more dominant difficulties in writing narrative texts.

\section{FINDINGS AND DISCUSSION}

\section{Findings}

The data collected by the researchers based on students' answer sheets of SMA Pangeran Antasari Medan. The first time that the researchers have been done, explained about narrative texts and asked the students to write narrative texts with the generic structures. Based on the researchers' observation at tenth grade of SMA Pangeran Antasari Medan. About the ability of students in writing narrative texts with the generic structures, the researchers have been done several stages starting from observation to data collection and found three categories of students' difficulties in writing Narrative text.

The categorizes made based on the students' answer sheets in writing Narrative texts. The things that recorded by the researchers for giving scores are the four generic structures: Orientation, Complication, Resolution, and Re-Orientation/ Coda. And the researchers found that the students still had difficulties in writing narrative text. 
Table 1 Table Scores of Students

\begin{tabular}{|c|c|c|c|}
\hline \multirow{2}{*}{ NAMES } & \multicolumn{3}{|c|}{ CATEGORIES } \\
\hline & LOW (00 - 59) & MEDIUM $(60-79)$ & HIGH $(80-100)$ \\
\hline Anggi Permata & & 65 & \\
\hline Amelia Saiputri & & 70 & \\
\hline Alya Annisa & & 70 & \\
\hline Ajeng Retno & 40 & & \\
\hline Dea Anisa & 35 & & \\
\hline Dwi Nandita & & & 85 \\
\hline Egilia Rui & & 75 & \\
\hline Fani Ardiana & & 75 & \\
\hline Fina Ardiani & & 70 & \\
\hline Indah Wulan Sari & & 65 & \\
\hline Icha Imelya & 55 & & \\
\hline ulia Marsya & & 70 & \\
\hline Kusmaida Santika & & 73 & \\
\hline Meivia Rahma & & 70 & \\
\hline Marcelia Berliani & & & 80 \\
\hline Nadya Rahma & & 65 & \\
\hline Noviles Laia & & 60 & \\
\hline Putri Adelia & & 70 & \\
\hline Ribka Nulo & 40 & & \\
\hline Selvi Tal & & 60 & \\
\hline Sella Alfiana & & 70 & \\
\hline Sherly & & & 80 \\
\hline Tasya Putri & & 75 & \\
\hline Riani Chanika & & 75 & \\
\hline Widia Alfiani & & 75 & \\
\hline Yun Yun Toppalim & & 65 & \\
\hline
\end{tabular}

\section{Discussion}

Based on the table scores above in writing narrative texts, there are 4 students who have a low category, 19 students have medium category and 3 students have a high category. Based on this data, the researchers concluded that the students still faced a problem in writing narrative texts especially to distinguish between
Orientation, Complication, Resolution, Re-Orientation/Coda. The students must practice at home and also ask their teacher to improve. 


\section{CONCLUSION}

\section{Conclusion}

Based on the research observation and findings above, it can be concluded that the tenth-grade students of SMA Pangeran Antasari still have difficulties in distinguishing between the generic structures in writing narrative texts. From 26 students, only 3 students can distinguish between four generic structures. and the rest must practice at home and ask their teacher to make improvements.

Then the researchers had some suggestions to improve the students' ability in facing difficulties in writing narrative texts. Firstly, the English Teacher should explain clearly about narrative texts and the generic structures of narrative texts. Make sure that the students understand it. Secondly, the English Teacher should make any improvements in teaching with methods or media to make students easy to understand parts of the generic structure in narrative texts. Finally, the English teacher should give a piece of advice to the students that English is easy to understand.

\section{REFERENCES}

Aryanty, Yurika. 2017. An Analysis of Students' Skill in Writing Narrative Text at Eight of SMP Negeri 7 TanjungPinang. TanjungPinang. Universitas Maritim Raja Ali Haji.

Diniya, Tabah Ghifary. 2013. An Analysis of Students' Ability and Difficulty in Writing Narrative Text (A Research Study Concerning Writing Skills of Eleventh Grade Students). Bandung. Universitas Pendidikan Indonesia.

Herlinawati. 2011. Error Analysis in the Students Writing Narrative Paragraph at MTsN Pajajaran Pamulang. Jakarta. State Islamic University Syarif Hidayatuallah.

King, Diana Hanbury. 2004. Writing Skills $\left(2^{\text {nd }}\right.$ Edition) Program Overview Grade 2-12. Cambridge: EPS Literacy and Intervention

Nuzhatun, Lana. 2016. An Analysis of Students' Problem in Writing Narrative Text: A Case Study at Second Grade Students of SMKN 1 Praya Tengah in Academic Year 2015/2016. Mataram. The University of Mataram.

Oshima, A. \& Hougue, A. 2007. Introduction to Academic Writing ( $3^{\text {rd }}$ Edition). New York: Longman. 
Putri, Yulia., Tavriyanti, Lisa. \& Roza, Welya. 2017. An Analysis of The Students' Difficulties in Writing Narrative Text at Second Grade Students of SMAN 1 Pelepat Muara Bungo Jambi. Sumatra Barat. Bung Hatta University.

Smalley, Regina L \& Ruetten, Mary K . 1986. Refining Composition Skills ( $2^{\text {nd }}$ Edition) Rhetoric and Grammar for ESL Students. New York: Macmillan Publishing Company. 